\title{
Comparison of slow freezing and vitrification methods for Venda cockerel's spermatozoa
}

\author{
Masindi L. Mphaphathi ${ }^{1,2}$, Dibungi Luseba ${ }^{2}$, Ben Sutherland ${ }^{2}$, \\ Tshimangadzo L. Nedambale $e^{1,2,3^{*}}$ \\ ${ }^{1}$ Agricultural Research Council, Animal Production Institute, Germplasm Conservation \& Reproductive Biotechnologies, Irene, RSA; \\ *Corresponding Author: lucky@arc.agric.za \\ ${ }^{2}$ Department of Animal Sciences, Faculty of Science, Tshwane University of Technology, Pretoria, RSA \\ ${ }^{3}$ Department of Animal, Wildlife and Grassland Sciences, University of the Free State, Bloemfontein, RSA
}

Received 22 April 2012; revised 25 May 2012; accepted 5 June 2012

\section{ABSTRACT}

An improvement in avian semen cryopreservation is essential and has the potential to improve the cryo-gene banking efficiency. This study compared two cryopreservation methods (slow freezing and vitrification) and the effect of different thawing/warming temperatures $\left(5^{\circ} \mathrm{C}, 25^{\circ} \mathrm{C}\right.$ and $41^{\circ} \mathrm{C}$ ) on Venda cockerel's spermatozoa. Semen samples from Venda cockerels were diluted with modified Kobidil ${ }^{+}$extender supplemented with $8 \%$ dimethyl sulfoxide. Semen from each ejaculate was stained with nigrosin/eosin for viability examination. The cryopreserved samples were either slow cooled in $0.25 \mathrm{~mL}$ straw or vitrified in a solid surface vitrification (SSV) device. Semen straw or cryovial was stored in liquid nitrogen container. The straw or cryovial with sperm was thawed or warmed at $5^{\circ} \mathrm{C}, 25^{\circ} \mathrm{C}$ and $41^{\circ} \mathrm{C}$ and analysed by a ComputerAided Sperm Analysis (CASA). There was a significant difference in live/normal sperm between the semen donors. Cockerels spermatozoa cryopreserved by slow freezing (43\%) and thawed at $5^{\circ} \mathrm{C}$ had a significantly higher survival and motility rate compared to vitrification (2.5\%) method. In conclusion, there was higher rate of livel normal morphology sperm. Cryopreservation process reduces sperm motility and velocity rate regardless of cryoprevervation method and thawing or warming temperatures. However, slow freezing was a better method to maintain motility of spermatozoa following cryopreservation.

Keywords: Venda Cockerels; Dimethyl Sulfoxide; Sperm Motility; Cryopreservation

\section{INTRODUCTION}

Improvements in avian semen cryopreservation protocols and related techniques have the potential to improve the cryo-gene banking efficiency and maintenance of biodiversity. Cockerel's semen cryopreservation technology is not yet suitable for commercial breeding due to lower sperm survival and motility rate [1]. In addition, artificial insemination with cryopreserved cockerel's sperm results in $80 \%$ loss of the fertility [2].

The Venda chicken breed is an important component of the unique South African gene pool diversity. It has its origins in a former homeland, the Venda region of the Limpopo Province in South Africa and is known to survive under harsh conditions [3]. The establishment of a cryo-bank is vital for the future poultry breeding programs. Moreover, the disappearance of a breed leads to the loss of its distinctive adaptive genes [4]. The development of a successful cryopreservation protocol for the cryopreservation of Venda cockerel's sperm should contribute significantly to the sustainable management of genetic resources and provide alternative preservation methods to be used in parallel with in situ conservation.

Cockerel's semen is routinely cryopreserved using the conventional slow freezing [5] or vapour methods [6]. The slow freezing method maintains the viability of cells or tissues indefinitely at very low temperatures. The temperature of the freezing chamber is reduced in a stepwise manner during cryopreservation process [7]. In addition, the discovery of a vitrification cryopreservation method resulted in a change in the principles of cryobiology. This method has many advantages over the slow freezing method, such as a lack of ice crystal formation due to an increase speed of temperature conduction which provides a significant increase in cooling rate [8]. This rapid cooling process bypasses the ice crystalline formation phase by converting solutions or water into a glass-like amorphous solid [8]. Vitrification also has an economic advantage than slow freezing method [9], 
however its disadvantage is the use of high concentration of cryoprotectant that could be toxic to cells [8,10].

Glycerol has been routinely used as the major cryoprotectant for sperm cryopreservation in most animal species including cockerels and pigeons [6,11]. However, glycerol has a contraceptive effect in poultry [12]. Alternative intracellular cryoprotectants tested on avian semen were dimethyl acetamide and dimethyl sulfoxide (DMSO) as they were alleged to have a lower toxicity [13], but penetrate the cell membrane rapidly which may make them toxic at high temperature. The DMSO is a standard cryoprotectant for poultry sperm cryopreservation and gives higher sperm motility recovery rate [2]. It has also been proven to be the best cryoprotectant in other avian studies with higher fertility and recovery motility [14].

There is a lack of data concerning the effect of slow freezing and vitrification method on cryopreserving Venda cockerel's semen. The aims of the study were to find the suitable cryopreservation method and thawing or warming temperatures of Venda cockerel's spermatozoa.

\section{MATERIALS AND METHODS}

\subsection{Study Site, Maintenance of Cockerels and Semen Collection}

The study was conducted at the Agricultural Research Council by the Germplasm Conservation and Reproductive Biotechnologies laboratory. All chemicals were analytical grade. Unless otherwise stated they were purchased from Sigma-Aldrich, Germany. The Kobidil ${ }^{+\circledR}$ extender was purchased from the Landata ${ }^{\circledR}$ Company, France. Experimental Venda cockerels were cared for according to the guidelines of the Care and Use of Animals Ethics Committee of the Agricultural Research Council (Ref: APIEC08/06). Cockerels were vaccinated at hatching against Marek's disease, infectious bronchitis and Newcastle Disease with live vaccines. They were transferred to individual battery cages in an open-sided chicken house at 24 weeks, fed a commercial diet (Epol ${ }^{\circledR}$ ) including water ad libitum and exposed to a photoperiod of 16 hours light. The semen collection study consisted of a 21 day adaptation and training period during summer (January until March 2009). The average body weight of the cockerels was $2.4 \mathrm{~kg}$. The method was based on that of Burrows and Quinn (1937), using an abdominal massage technique for semen collection [15]. Ejaculates were collected in a $15 \mathrm{ml}$ tube (Falcon ${ }^{\circledR}$ 352099, USA) and placed in a thermo flask containing water at $41^{\circ} \mathrm{C}$ to maintain the temperature. The semen was transported to the laboratory within 10 minutes of collection.

\subsection{Semen Evaluation and Freezing}

Five microlitres of diluted semen were placed on a warm glass slide $(76 \times 26 \times 1 \mathrm{~mm})$ and placed with a warmed cover slip $(22 \times 22 \mathrm{~mm})$ before transferring to a microscope warm plate adjusted to $37^{\circ} \mathrm{C}$ [16]. The sperm motility rate (non progressive, progressive, slow, medium, and rapid) and the velocity on the curve line were evaluated and recorded using a Sperm Class Analyzer ${ }^{\circledR}$ (SCA-Microptic ${ }^{\circledR}$, Spain). Semen sample for slow freezing group was diluted with modified Kobidil ${ }^{+}$extender supplemented with $8 \% \mathrm{DMSO}$ and equilibrated at $5^{\circ} \mathrm{C}$. It was then loaded into $0.25 \mathrm{ml}$ straws and placed in a portable programmable freezer (Halikan 88 LX 2002 ${ }^{\circledR}$, Taiwan). The initial freezing temperature of $5^{\circ} \mathrm{C}$ was reduced at a rate of $1^{\circ} \mathrm{C}$ per minute until the target temperature of $-20^{\circ} \mathrm{C}$ was reached and held for 5 minutes. The straws were then suspended $4-6 \mathrm{~cm}$ above liquid nitrogen vapour for 5 minutes and then plunged directly into an ice box containing liquid nitrogen $\left(-196^{\circ} \mathrm{C}\right)$ for an additional 5 minutes. Semen straws were transferred into a liquid nitrogen container at $-196^{\circ} \mathrm{C}$ for storage. After three months, the straws were thawed in a refrigerator at $5^{\circ} \mathrm{C}$ for 5 minutes or at $25^{\circ} \mathrm{C}$ for 1 minute or at $41^{\circ} \mathrm{C}$ for 1 minute.

The precooling procedures were also used for the SSV method. Following an equilibration period, $5 \mu \mathrm{l}$ of diluted semen were dropped into a pre-cooled SSV device. The drops were loaded into a pre-cooled cryovial (Cryogenic vial $^{\circledR}$, Mexico) with pre-cooled forceps. The cryovials were then removed from the SSV device and placed in an aluminium cryo-cane (Jencons-PLS) and stored in a liquid nitrogen container. Before warming, the SSV device was equilibrated in an ice box filled with liquid nitrogen for approximately 15 minutes. Vitrified semen drops were warmed at $5^{\circ} \mathrm{C}$ for 5 minutes or $25^{\circ} \mathrm{C}$ for 1 minute or at $41^{\circ} \mathrm{C}$ for 1 minute.

\subsection{Statistical Analysis}

Data were analysed using the statistical program GenStat $^{\circledR}$. A significance level of $0.05 \%$ was used $(\mathrm{P}<0.05)$. Analysis of variance (ANOVA) was used to test differences on cryopreservation methods and thawing or warming temperatures on sperm motility and velocity rate. Treatment means were separated using the Fishers' protected $t$-test least significant difference (LSD). The data are presented as mean \pm SD.

\section{RESULTS}

Sperm viability results are indicated in Table 1. Over $87 \%$ of the sperm viability was alive and normal. Venda cockerel 6 (VC6) had a higher sperm viability (94.7\%) than VC2 (87.7\%) and VC4 (89.7\%). However, VC6 (94.7\%) sperm viability did not differ with VC5 (94.3\%), VC1 (91.7\%) and VC3 (96.3\%). There was a significant difference in the live/normal sperm morphology between 
the semen donors. There was no statistical difference in the percentage of head and mid-piece abnormalities of the live sperm.

A comparison of the slow freezing and vitrification on the sperm motility rate following thawing or warming is indicated in Table 2. The conventional slow freezing method resulted in a higher total sperm motility rate (43\%) compared to the vitrification method (2.5\%). All cryopreservation methods reduced the sperm motility rate compared to the control $(91.2 \%$, non-cryopreserved sperm) regardless of the thawing or warming temperatures.

The effect of cryopreservation on the straightness, linearity and wobbling velocity of Venda cockerel's sperm is indicated in Table 3. The velocity on the straight line (80.7 $\mu \mathrm{m} / \mathrm{s})$, average path $(57.3 \mu \mathrm{m} / \mathrm{s})$, linearity (58.3\%), straightness (82.8\%), wobble $(67.0 \%)$ and beat cross frequency $(13.9 \mathrm{~Hz})$ were not significantly affected by the conventional slow freezing method. The sperm velocity on the straight line $(102.6 \mu \mathrm{m} / \mathrm{s})$, average path (81.9 $\mu \mathrm{m} / \mathrm{s})$, linearity (64.7\%), straightness (80.5\%), wobble $(71.7 \%)$ and beat cross frequency $(12.8 \mathrm{~Hz})$ for vitrification method were not significantly different compared to slow freezing method $(\mathrm{P}>0.05)$.

Venda cockerel's sperm motility and velocity rate were affected by all thawing temperatures $\left(5^{\circ} \mathrm{C}, 25^{\circ} \mathrm{C}\right.$ and $41^{\circ} \mathrm{C}$ ). The cryopreservation process decreased the sperm motility significantly, irrespective of thawing conditions (Table 4). Thawing cockerel's sperm at $5^{\circ} \mathrm{C}$ (45.5\%) resulted in higher motility rate in slow freezing method compared to thawing at $25^{\circ} \mathrm{C}(17.6 \%)$ and $41^{\circ} \mathrm{C}(0.7 \%)$, respectively. Sperm were immotile in the group with no cryoprotectant (No CPA) when thawed at both $25^{\circ} \mathrm{C}$ and $41^{\circ} \mathrm{C}$.

Table 1. Venda cockerel's sperm morphology (mean \pm SD).

\begin{tabular}{|c|c|c|c|c|c|}
\hline \multirow{2}{*}{ Venda cockerels (VC) } & \multirow{2}{*}{ Live normal (\%) } & \multirow{2}{*}{ Dead (\%) } & \multicolumn{3}{|c|}{ Live sperm abnormalities (\%) } \\
\hline & & & Head & Mid-piece & Tail \\
\hline VC2 & $87.7 \pm 1.5^{c}$ & $2.3 \pm 2.1^{\mathrm{a}}$ & $1.3 \pm 1.5$ & $2.0 \pm 1.0$ & $6.7 \pm 1.2^{\mathrm{a}}$ \\
\hline VC3 & $96.3 \pm 0.6^{\mathrm{a}}$ & $0.3 \pm 0.6^{\mathrm{b}}$ & $1.0 \pm 1.7$ & $0.3 \pm 0.6$ & $2.0 \pm 1.7^{\mathrm{b}}$ \\
\hline VC4 & $89.7 \pm 4.5^{c}$ & $0.7 \pm 1.1^{\mathrm{ab}}$ & $4.0 \pm 1.0$ & $2.7 \pm 3.1$ & $3.0 \pm 2.0^{b}$ \\
\hline VC5 & $94.3 \pm 2.1^{\mathrm{ab}}$ & $0.7 \pm 1.1^{\mathrm{ab}}$ & $3.3 \pm 2.3$ & $0.7 \pm 0.7$ & $1.0 \pm 1.0^{\mathrm{b}}$ \\
\hline VC6 & $94.7 \pm 2.9^{\mathrm{ab}}$ & $0.7 \pm 1.2^{\mathrm{ab}}$ & $2.0 \pm 1.0$ & $0.0 \pm 0.0$ & $2.7 \pm 1.5^{b}$ \\
\hline Average & 92.4 & 0.8 & 2.4 & 1.3 & 3.2 \\
\hline
\end{tabular}

${ }_{\mathrm{a}, \mathrm{b}, \mathrm{c}}$ Values with different superscript within a column are significantly different $(\mathrm{P}<0.05)$.

Table 2. The effect of cryopreservation method on Venda cockerel's sperm motility rate after thawed/warmed at $5^{\circ} \mathrm{C}$ (mean \pm SD).

\begin{tabular}{|c|c|c|c|c|c|c|}
\hline Treatment & TM (\%) & PM (\%) & NPM (\%) & SLW (\%) & MED (\%) & RAP (\%) \\
\hline Fresh semen & $91.2 \pm 7.4^{\mathrm{a}}$ & $58.6 \pm 20.7^{a}$ & $32.6 \pm 15.2^{\mathrm{a}}$ & $18.8 \pm 16.4^{\mathrm{a}}$ & $14.5 \pm 7.2^{\mathrm{a}}$ & $57.9 \pm 21.6^{\mathrm{a}}$ \\
\hline Slow freezing & $43.0 \pm 7.9^{b}$ & $21.6 \pm 9.7^{b}$ & $21.4 \pm 8.1^{b}$ & $12.6 \pm 8.0^{\mathrm{a}}$ & $16.3 \pm 4.9^{\mathrm{a}}$ & $14.1 \pm 9.0^{b}$ \\
\hline Vitrification & $2.5 \pm 0.9^{c}$ & $2.3 \pm 1.2^{\mathrm{c}}$ & $0.2 \pm 0.7^{\mathrm{c}}$ & $0.0 \pm 0.0^{\mathrm{b}}$ & $0.8 \pm 1.1^{\mathrm{b}}$ & $1.7 \pm 1.1^{\mathrm{c}}$ \\
\hline
\end{tabular}

$\overline{\mathrm{a}, \mathrm{b}, \mathrm{c}}$ Values with different superscripts within the column are statistically different $(\mathrm{P}<0.05)$.

Table 3. Effect of cryopreservation method on Venda cockerel's sperm velocity rate after thawed/warmed at $5^{\circ} \mathrm{C}$ (mean \pm SD).

\begin{tabular}{|c|c|c|c|c|c|c|c|c|}
\hline Treatment & $\begin{array}{c}\text { VCL } \\
(\mu \mathrm{m} / \mathrm{sec})\end{array}$ & $\begin{array}{c}\text { VSL } \\
(\mu \mathrm{m} / \mathrm{sec})\end{array}$ & $\begin{array}{c}\text { VAP } \\
(\mu \mathrm{m} / \mathrm{sec})\end{array}$ & $\begin{array}{l}\text { LIN } \\
(\%)\end{array}$ & $\begin{array}{l}\text { STR } \\
(\%)\end{array}$ & $\begin{array}{l}\text { WOB } \\
(\%)\end{array}$ & $\begin{array}{l}\text { ALH } \\
(\mu \mathrm{m})\end{array}$ & $\begin{array}{l}\text { BCF } \\
(\mathrm{Hz})\end{array}$ \\
\hline Fresh semen & $124.1 \pm 39.9^{a}$ & $81.3 \pm 37.7$ & $93.7 \pm 40.0$ & $63.1 \pm 12.6$ & $85.5 \pm 5.7$ & $73.5 \pm 10.7$ & $3.0 \pm 0.3^{\mathrm{a}}$ & $16.0 \pm 1.5$ \\
\hline Slow freezing & $80.7 \pm 23.7^{\mathrm{ab}}$ & $48.1 \pm 18.1$ & $57.3 \pm 19.7$ & $58.3 \pm 9.2$ & $82.8 \pm 5.7$ & $67.0 \pm 6.8$ & $2.3 \pm 0.3^{b}$ & $13.9 \pm 4.6$ \\
\hline Vitrification & $102.6 \pm 43.5^{b}$ & $75.3 \pm 41.9$ & $81.9 \pm 41.6$ & $64.7 \pm 29.9$ & $80.5 \pm 29.1$ & $71.7 \pm 28.3$ & $2.0 \pm 1.1^{\mathrm{b}}$ & $12.8 \pm 9.0$ \\
\hline
\end{tabular}

${ }^{\mathrm{a} b}$ Values with different superscripts within the column differs statistical $(\mathrm{P}<0.05)$. 
Venda cockerels sperm motility rate were affected by all three warming temperatures (Table 5). Warming at $5^{\circ} \mathrm{C}, 25^{\circ} \mathrm{C}$ and $41^{\circ} \mathrm{C}$ resulted in a motility rate of $2.1 \%$, $1.2 \%$ and $0.0 \%$, respectively in $8 \%$ DMSO compared to $1.4 \%, 0.0 \%$ and $0.0 \%$ in No CPA. The No CPA group resulted in immotile sperm when thawed at both $25^{\circ} \mathrm{C}$ and $41^{\circ} \mathrm{C}$.

\section{DISCUSSION}

Cryopreservation of Venda cockerel's sperm with slow freezing method and thawing at $5^{\circ} \mathrm{C}$ resulted in a higher motility rate. However, the cryopreservation process was found to reduce the sperm viability and velocity rate regardless of thawing or warming temperatures. The gene pool of the Venda chicken with its adaptive traits contributes to the rich biodiversity of South Africa. Nigrosin/eosin was used to stain sperm of Venda cockerels for viability analysis. This is a double stain based on the degree of permeability of dead sperm membranes and non-permeability in live sperm membranes [17]. Most of the ejaculates with live and normal sperm were greater than $91 \%$ in the Venda cockerels. There were individual variations in the proportion of their live and normal sperm morphology. Tseluten, Seigneurin and Blesbois [18] reported a 92\% - 94\% normal morphology in commercial breed. However, a lower percentage (87.0\% 89.1\%) was reported by Ansah, Segura and Buckland [19]. These results are similar to the findings of the present study. Gendy, Gad and Mostageer [20] recorded a percentage of live sperm of $94.8 \%$ and morphologically abnormal sperm of $3.4 \%$ in broiler males. This was comparable to the results of the present study. Rwuaan et al. [21] recorded sperm abnormalities of 3.3\%. Tuncer, Kinet and Ozxdogan [22] reported a higher proportion of dead cells (6.32\%) and $19.74 \%$ sperm with morphological abnormalities. Variations the live, normal sperm of avian species may be also influenced by the breed. The results from this study indicated a variation between individual Venda cockerels.

Table 4. The effect of the slow freezing method and thawing temperatures on Venda cockerel's sperm motility rate (mean \pm SD).

\begin{tabular}{|c|c|c|c|c|c|c|c|}
\hline \multirow{2}{*}{ Temperature } & Treatment & TM (\%) & PM (\%) & NPM (\%) & SLW (\%) & MED (\%) & RAP (\%) \\
\hline & Fresh semen & $92.5 \pm 7.2^{\mathrm{a}}$ & $59.1 \pm 19.8^{\mathrm{a}}$ & $33.3 \pm 14.6^{\mathrm{a}}$ & $17.8 \pm 15.1^{a}$ & $14.7 \pm 6.6^{b}$ & $59.9 \pm 21.5^{\mathrm{a}}$ \\
\hline \multirow{2}{*}{$5^{\circ} \mathrm{C}$} & 8\% DMSO & $45.5 \pm 8.0^{b}$ & $22.8 \pm 9.0^{b}$ & $22.7 \pm 8.6^{b}$ & $13.7 \pm 7.7^{\mathrm{a}}$ & $17.4 \pm 4.6^{\mathrm{a}}$ & $14.3 \pm 7.8^{b}$ \\
\hline & No CPA & $3.8 \pm 5.4^{\mathrm{d}}$ & $1.2 \pm 1.7^{\mathrm{d}}$ & $2.6 \pm 4.3^{\mathrm{cd}}$ & $2.3 \pm 3.8^{\mathrm{bc}}$ & $1.1 \pm 1.7^{\mathrm{d}}$ & $0.4 \pm 0.6^{\mathrm{c}}$ \\
\hline \multirow{2}{*}{$25^{\circ} \mathrm{C}$} & 8\% DMSO & $17.6 \pm 8.0^{c}$ & $10.5 \pm 5.6^{\mathrm{c}}$ & $7.1 \pm 3.7^{c}$ & $4.9 \pm 3.9^{b}$ & $6.9 \pm 4.4^{c}$ & $5.2 \pm 2.9^{c}$ \\
\hline & No CPA & $0.0 \pm 0.0^{\mathrm{e}}$ & $0.0 \pm 0.0^{\mathrm{d}}$ & $0.0 \pm 0.0^{\mathrm{d}}$ & $0.0 \pm 0.0^{c}$ & $0.0 \pm 0.0^{\mathrm{d}}$ & $0.0 \pm 0.0^{c}$ \\
\hline \multirow{2}{*}{$41^{\circ} \mathrm{C}$} & 8\% DMSO & $0.7 \pm 1.1^{\mathrm{de}}$ & $0.42 \pm 1.0^{\mathrm{d}}$ & $0.3 \pm 0.7^{\mathrm{d}}$ & $0.3 \pm 0.7^{\mathrm{bc}}$ & $0.0 \pm 0.0^{\mathrm{d}}$ & $0.4 \pm 1.0^{\mathrm{c}}$ \\
\hline & No CPA & $0.0 \pm 0.0^{\mathrm{e}}$ & $0.0 \pm 0.0^{\mathrm{d}}$ & $0.0 \pm 0.0^{\mathrm{d}}$ & $0.0 \pm 0.0^{c}$ & $0.0 \pm 0.0^{\mathrm{d}}$ & $0.0 \pm 0.0^{c}$ \\
\hline
\end{tabular}

$\overline{\mathrm{a}, \mathrm{b}, \mathrm{c}, \mathrm{d}}$ Values with different superscripts within the column differs statistical $(\mathrm{P}<0.05)$.

Table 5. The effect of vitrification and warming temperatures on Venda cockerel's sperm motility rate (mean \pm SD).

\begin{tabular}{|c|c|c|c|c|c|c|c|}
\hline \multirow{2}{*}{ Temperature } & Treatment & TM (\%) & PM (\%) & NPM (\%) & SLW (\%) & MED (\%) & RAP (\%) \\
\hline & Fresh semen & $81.8 \pm 30.0^{\mathrm{a}}$ & $43.7 \pm 18.2^{\mathrm{a}}$ & $38.1 \pm 15.8^{\mathrm{a}}$ & $20.0 \pm 10.9^{\mathrm{a}}$ & $19.2 \pm 10.5^{\mathrm{a}}$ & $42.6 \pm 19.9^{a}$ \\
\hline \multirow{2}{*}{$5^{\circ} \mathrm{C}$} & 8\% DMSO & $2.1 \pm 1.2^{\mathrm{b}}$ & $1.8 \pm 1.3^{\mathrm{b}}$ & $0.4 \pm 1.1^{\mathrm{b}}$ & $0.1 \pm 0.3^{b}$ & $0.7 \pm 1.0^{\mathrm{b}}$ & $1.4 \pm 1.1^{\mathrm{b}}$ \\
\hline & No CPA & $1.4 \pm 1.2^{\mathrm{b}}$ & $0.9 \pm 0.8^{b}$ & $0.5 \pm 0.7^{\mathrm{b}}$ & $0.4 \pm 0.7^{\mathrm{b}}$ & $0.6 \pm 0.7^{\mathrm{b}}$ & $0.4 \pm 0.8^{b}$ \\
\hline \multirow[b]{2}{*}{$25^{\circ} \mathrm{C}$} & 8\% DMSO & $1.2 \pm 0.9^{\mathrm{b}}$ & $0.6 \pm 0.8^{\mathrm{b}}$ & $0.6 \pm 0.9^{\mathrm{b}}$ & $0.6 \pm 0.9^{\mathrm{b}}$ & $0.4 \pm 0.6^{\mathrm{b}}$ & $0.3 \pm 0.6^{\mathrm{b}}$ \\
\hline & No CPA & $0.0 \pm 0.0^{\mathrm{b}}$ & $0.0 \pm 0.0^{\mathrm{b}}$ & $0.0 \pm 0.0^{\mathrm{b}}$ & $0.0 \pm 0.0^{\mathrm{b}}$ & $0.0 \pm 0.0^{\mathrm{b}}$ & $0.0 \pm 0.0^{\mathrm{b}}$ \\
\hline \multirow[b]{2}{*}{$41^{\circ} \mathrm{C}$} & 8\% DMSO & $0.0 \pm 0.0^{\mathrm{b}}$ & $0.0 \pm 0.0^{\mathrm{b}}$ & $0.0 \pm 0.0^{\mathrm{b}}$ & $0.0 \pm 0.0^{\mathrm{b}}$ & $0.0 \pm 0.0^{\mathrm{b}}$ & $0.0 \pm 0.0^{\mathrm{b}}$ \\
\hline & No CPA & $0.0 \pm 0.0^{\mathrm{b}}$ & $0.0 \pm 0.0^{\mathrm{b}}$ & $0.0 \pm 0.0^{\mathrm{b}}$ & $0.0 \pm 0.0^{\mathrm{b}}$ & $0.0 \pm 0.0^{\mathrm{b}}$ & $0.0 \pm 0.0^{\mathrm{b}}$ \\
\hline
\end{tabular}

${ }^{\mathrm{a}, \mathrm{b}}$ Values with different superscripts within the column differ statistical $(\mathrm{P}<0.05)$. 
There is lack of available information related to the cryopreservation of Venda cockerel's sperm and this is the first attempt to characterise Venda cockerels sperm motility rate analysed by the $\mathrm{SCA}^{\circledR}$ system following cryopreservation. Slow cooling of sperm was a better cryopreservation method compared to vitrification method. Good quality sperm has been reported to be more likely to withstand the cryopreservation and thawing process [23]. The CASA provides an objective means of establishing sperm motility and velocity rate in a given population [24]. Lower values for sperm velocity on the straight line (33.65 $\mu \mathrm{m} / \mathrm{s})$, average path $(47.98$ $\mu \mathrm{m} / \mathrm{s}$ ), linearity (32.94\%) and straightness (67.66\%) of thawed semen from cockerels have been reported [24]. Computer-aided sperm motility analysis parameters have been suggested as predictors of sperm cryosurvival in cockerels. Lower values compromised the ability of thawed sperm from each line to hydrolyze the inner perivitelline membrane and are perhaps the most significant assessment of fertilizing ability [24]. These results were not comparable to the present findings in Venda cockerels. This might be due to the type of chicken breed and the type of extender used. Previously reported values of thawed sperm velocity on the average path of 55.7 $\mu \mathrm{m} / \mathrm{s}$, straight line $41.2 \mu \mathrm{m} / \mathrm{s}$, straightness $68.7 \%$ and linearity $42.0 \%$ on rooster sperm were slightly lower compared to the present study [24]. There was a significant difference in sperm velocity on the curve line between fresh and vitrified sperm. Cryopreserved sperm in slow freezing and thawing at $5^{\circ} \mathrm{C}$ resulted in a higher motility rate compared to vitrification method. In a previous report that used a subjective method to evaluate the post-thaw sperm motility rate, duck sperm thawed at $20^{\circ} \mathrm{C}$ and $40^{\circ} \mathrm{C}$ had a post-thaw motility rate of $29 \%$ and $62 \%$, respectively [25] which is in contrast to the present study. The results of the Venda cockerels suggest that the thawing temperature influences the post-thaw motility rate and that the species used as a semen donor plays a critical role. Furthermore, the presence of cryoprotectant in cryopreservation solutions plays a major role. Higher sperm motility (44.4\%) was reported when human semen was vitrified [26], which is in contrast to this study.

It has been reported that the critical steps in the successful cryopreservation of fowl sperm depends on the choice of cryoprotectant [27], extender, cooling rate and thawing conditions [28]. Sperm membrane damages or death during the cryopreservation process is related to the formation of large amounts of ice crystal [29]. In the present study the motility rate of vitrified sperm was dramatically affected by the size of vitrification droplets which affected the shape and size of the sperm head, one of the factors that has been reported to define cryosensitivity. Less cytoplasmic volume and therefore, less efficient to move cryoprotectant inside the sperm head may be a further reason that avian sperm do not survive the cryopreservation process well [2]. In addition, compared to mammals, avian sperm possess unique physiological features which make their viability being compromised under cryopreservation conditions [2].

A post-thaw sperm motility of $45 \%, 47 \%$ and $40 \%$ on Ovambo, Potchefstroom Koekoek and White Leghorn breeds respectively have been recorded [30]. Although these results are comparable to the present study, a subjective method was used to evaluate the post-thaw sperm motility rate. The sperm motility rate was also reported to decrease during freezing and thawing in other avian species such as vultures and pheasants [31,32]. During slow cooling, fast cooling and thawing of cockerel's sperm, the cells undergo chemical and physical changes. Each of these steps has the potential to damage the functionality of the sperm membrane. In addition, each step adversely affects the sperm motility rate during the thawing or warming process. Poorly motile sperm, such as those categorised as slow and medium, are less likely to progress and bind the ova for fertilization. Freezing and thawing has been reported to decrease sperm motility rate, and membrane alternations definitely affect sperm fertility [33]. Cryopreservation therefore reduces sperm lifespan and limits their progression within the female reproductive organ [34]. Furthermore, cryopreservation has been reported to vary among species and individual ejaculates in the same animal or breed [35,36]. Thus suitable cryopreservation methods should be developed to facilitate the storage of cockerel's sperm in liquid nitrogen $\left(-196^{\circ} \mathrm{C}\right)$ for long periods without loss of motility rate and viability.

In conclusion, cryopreserving Venda cockerel's sperm in slow freezing method and thawing at $5^{\circ} \mathrm{C}$ resulted in a higher motility rate. However, the cryopreservation process reduced the sperm motility and velocity rate regardless of thawing or warming temperatures. Further studies are required to conduct artificial insemination for quantification of the better sperm fertility obtained following slow freezing method.

\section{ACKNOWLEDGEMENTS}

The study was supported by a grant from Department of Agriculture Forestry and Fishery Directorate of Genetic Resources, Professional Development Programme 3014MM Grant. The Germplasm Conservation \& Reproductive Biotechnologies group is thanked for their support.

\section{REFERENCES}

[1] Fulton, J.E. (2006) Avian genetic preservation: An industry perspective. Poultry Science, 85, 227-231.

[2] Donoghue, A.M. and Wishart, G.J. (2000) Storage of 
poultry semen. Animal Reproduction Science, 62, 213232. doi:10.1016/S0378-4320(00)00160-3

[3] Van Marle-Koeste, E., Hefer, C.A., Nel, L.H. and Groenen, M.A.M. (2008) Genetic diversity and population structure of locally adapted South African chicken lines: implications for conservation. South African Journal of Animal Science, 38, 271-281.

[4] Long, J.A. (2008) Reproductive biotechnology and gene mapping: tools for conserving rare breeds of livestock. Reproduction of Domestic Animals, 43, 83-88. doi:10.1111/j.1439-0531.2008.01146.x

[5] Blanco, J.M., Gee, G., Wildt, D.E. and Donoghue, A.M. (2000) Species variation in osmotic, cryoprotectant, and cooling rate tolerance in poultry, eagle and Peregrine falcon spermatozoa. Biology of Reproduction, 63, 11641171. doi:10.1095/biolreprod63.4.1164

[6] Purdy, P.H., Song, Y., Silversides, F.G. and Blackburn, H.D. (2009) Evaluation of glycerol removal techniques, cryoprotectants, and insemination methods for cryopreservation rooster sperm with implications of regeneration of breed or line or both. Poultry Science, 88, 2184-2191. doi:10.3382/ps.2008-00402

[7] Williamson, R.G., Etchers, R.J., Reinhart, B.S. and Macpherson, J.W. (1981) The effect of cooling rate before freezing and the temperature of the semen upon addition of DMSO on the fertilizing capacity of chicken semen stored at $-196^{\circ} \mathrm{C}$. Reproduction of Nutrition and Development, 21, 1033-1042. doi:10.1051/rnd:19810801

[8] Dinnyes, A., Liu, J. and Nedambale, T.L. (2007) Novel gamete storage. Reproduction of Fertility and Development, 19, 719-731. doi:10.1071/RD07035

[9] Ozkavukcu, S. and Erdemli, E. (2000) Cryopreservation: basic knowledge and biophysical effects. Journal of Ankara Medical School, 4, 187-196.

[10] Nedambale, T.L., Dinnyes, A., Yang, X. and Tian, C. (2004) Bovine blastocyst development in vitro: Timing, sex, and viability following vitrification. Biology of Reproduction, 71, 1671-1676. doi:10.1095/biolreprod.104.027987

[11] Parksw, E.J., Heck, W.R. and Hardaswick, V. (1986) Cryopreservation of Peregrine falcon semen post-thaw dialysis to remove glycerol. Raptor Research, 20, 15-20.

[12] Long, J.A. and Kulkarin, G. (2004) An effective method for improving the fertility of glycerol-exposed poultry semen. Poultry Science, 83, 1594-1601.

[13] Lake, P.E. and Ravie, O. (1984) An exploration of cryoprotective compounds for fowl spermatozoa. British Poultry Science, 25, 145-150. doi:10.1080/13632758408454852

[14] Sontakke, S.D., Umapathy, G., Sivaram, V., Kholkutel, S.D. and Shivaji, S. (2004) Semen characteristics, cryopreservation, and successful artificial insemination in the Blue rock pigeon (Columba livia). Theriogenology, 62, 139-153. doi:10.1016/j.theriogenology.2003.08.018

[15] Burrows, H.W. and Quinn, J.P (1937) The collection of spermatozoa from the domestic fowl and turkey. Poultry Science, 16, 185-191. doi:10.3382/ps.0160019
[16] EI-Gendy, E.A., Gad, A.Y. and Mostageer, A. (2007) Sperm-mediated gene transfer in poultry. The relationship with cock sperm viability. Arab Journal of Biotechnology, 10, 1-12.

[17] Lukaszewick, E., Jerysz, A., Partyka, A. and Siudzinska, A. (2008) Efficacy of evaluation of rooster sperm morphology using different staining methods. Research in Veterinary Science, 85, 583-588. doi:10.1016/j.rvsc.2008.03.010

[18] Tselutin, K., Seigneurin, F. and Blesbois, E. (1999) Comparison of cryoprotectants and methods of cryopreservation of fowl spermatozoa. Poultry Science, 78, 586590.

[19] Ansah, G.A., Segura, J.C. and Buckland, R.B. (1985) Semen production, sperm quality, and their heritabilities as influenced by selection for fertility of frozen-thawed semen in the chicken. Poultry Science, 64, 1801-1803. doi:10.3382/ps.0641801

[20] Gendy, E.A., Gad, A.Y. and Mostageer, A (2007) Spermmediated gene transfer in poultry. The relationship with cock sperm viability. Arab Journal of Biotechnology, 10, $1-12$.

[21] Rwuaan, J.S., Rekwot, P.I., Abdu, P.A., Eduvie, L.O. and Obidi, J.A. (2009) Semen characteristics of vaccinated Shikabrown cocks challenged with a velogenic Newcastle disease virus. International Journal of Poultry Science, $\mathbf{8}$, 896-90. doi:10.3923/ijps.2009.896.901

[22] Tuncer, P.B., Kinet, H. and Ozdogan, N. (2008) Evaluation of some spermatological characteristics in Gerze cocks. Ankara University of Veterinarian Dergree, 55, 99102.

[23] Blesbois, E., Grasseau, I., Seigneurin, F., MignonGrasteau, S., Saint-Jalme, M. and Milalon-Richard, M.M. (2008) Predictors of success of semen cryopreservation in chickens. Theriogenology, 69, 349-359. doi:10.1016/j.theriogenology.2007.09.019

[24] Long, J.A., Bongalhardo, D.C., Pelaez, J., Saxena, S., Settar, P., O'Sullivan, N.P. and Fulton, J.E. (2010) Rooster semen cryopreservation: Effect of pedigree line and male age on post thaw sperm function. Poultry Science, 89, 966-973. doi:10.3382/ps.2009-00227

[25] Han, X.F., Niu, Z.Y., Liu, F.Z. and Yang, C.S. (2005) Effects of diluents, cryoprotectants, equilibration time and thawing temperature on cryopreservation of duck semen. Poultry Science, 4, 197-201. doi:10.3923/ijps.2005.197.201

[26] Peirouvi, T., Farjah, G., Rad, J.S. and Novin, M.G. (2007) Vitrification induced apoptosis in spermatozoa from fertile and subfertile men. Iran Journal of Reproductive Medicine, 5, 117-120.

[27] Tselutin, K., Seigneurin, F. and Blesbois, E. (1999) Comparison of cryoprotectants and methods of cryopreservation of fowl spermatozoa. Poultry Science, 78, 586590.

[28] Siudzinska, A. and Lukaszewicz, E. (2008) The effect of breed on freezability of semen of fancy fowl. Animal Science Papers and Reports, 26, 331-340.

[29] Orief, Y., Schultze-Mosgau, A., Dafopoulos, K., AI- 
Hasani, S. (2005) Vitrification: Will it replace the conventional gamete cryopreservation techniques? Middle East Fertility Society Journal, 10, 171-184.

[30] Makhafola, M.B, Lehloenya, K.C., Mphaphathi, M.L., Dinnyes, A. and Nedambale, T.L. (2009) The effect of breed on the survivability and motility rate of cryopreserved cock semen. South African Journal of Animal Science, 39, 242-245.

[31] Jalme, M.S., Lecoq, R., Seigneurin, F., Blesbois, E. and Plouzeau, E. (2003) Cryopreservation of semen from endangered pheasants:the first step towards a cryobank for endangered avian species. Therionelogy, 59, 875-888. doi:10.1016/S0093-691X(02)01153-6

[32] Madedu, M., Berlinguer, F., Ledda, M., Leoni, G.G., Satta, V., Succu, S., Rotta, A., Pasciu, V., Zinellu, A., Muzzeddu, M., Carru, C. and Naitana, S. (2009) Ejaculate collection efficiency and post-thaw semen quality in wild-caught Griffon vultures from the Sardinian population. Reproductive Biology Endocrinology, 7, 1-11. doi:10.1186/1477-7827-7-18

[33] Martin, G., Cagnon, N., Sabido, O., Sion, B., Grizard, G.,
Durand, P. and Levy, R. (2007) Kinetics of occurrence of some features of apoptosis during the cryopreservation process of bovine spermatozoa. Human Reproduction, 22, 380-388. doi:10.1093/humrep/del399

[34] Ortega-Ferrulosa, C., Sotillio-Galan, Y., Varela-Fernandez, E., Gallardo-Bolanos, J.M., Muriel, A., Gonzalez-Fernandez, L., Tapia, J.A and Pena, F.J. (2008) Detection of "apoptosis-like" changes during the cryopreservation process in equine sperm. Journal of Andrology, 29, 213221. doi:10.2164/jandrol.107.003640

[35] Waterhouse, K.E., Hofmo, P.O., Tverdal, A. and Miller, R.R. (2006) Within and between breed differences in freezing tolerance and plasma membrane fatty acid composition of boar sperm. The Journal of the Animal Society for Reproduction and Fertility, 131, 887-894. doi:10.1530/rep.1.01049

[36] Defoin, L., Granados, A. and Donnay, I. (2007) Analysing motility parameters on fresh bull semen could help to predict resistance to freezing: A preliminary study. Reproduction in Domestic Animals, 43, 606-611. doi:10.1111/j.1439-0531.2007.00964.X 